\title{
Pengaruh Model Pembelajaran Inkuiri Terbimbing Terhadap Pemahaman Konsep Siswa pada Mata Pelajaran Fisika di SMP Negeri 19 Palu
}

\author{
Dahrinto A. Maladjuna, Sahrul Saehana dan Syamsu \\ e-mail: dahri07maladjuna@gmail.com \\ Program Studi Pendidikan Fisika FKIP Universitas Tadulako \\ Jl. Soekarno Hatta Km. 9 Kampus Bumi Tadulako Tondo Palu - Sulawesi Tengah
}

\begin{abstract}
ABSTRAK
Penelitian ini bertujuan untuk mengetahui pengaruh penerapan model pembelajaran inkuiri terbimbing terhadap pemahaman konsep siswa pada mata pelajaran fisika di SMP Negeri 19 Palu. Sampel dalam penelitian adalah siswa kelas VIII D SMP Negeri 19 Palu yang berjumlah 20 orang. Hasil analisis data menunjukkan bahwa skor ratarata tes awal sebesar 15,7 dan skor rata-rata tes akhir sebesar 30,35 dari 41 skor maksimal. Pengujian hipotesis menggunakan statistik non parametrik uji-t diperoleh thitung $=11,91 t_{\text {tabel }}=60$ pada $a=0,05$. Berdasarkan hasil yang diperoleh yaitu $t_{\text {hitung }}<t_{\text {tabel }}$ dapat disimpulkan bahwa terdapat pengaruh yang signifikan pada pemahaman konsep siswa setelah diterapkan model pembelajaran inkuiri terbimbing.
\end{abstract}

Kata Kunci: Model Pembelajaran, Inkuiri Terbimbing, Pemahaman Konsep

\section{PENDAHULUAN}

Proses pembelajaran terjadi melalui banyak cara baik disengaja maupun tidak disengaja dan berlangsung sepanjang waktu dan menuju pada suatu perubahan pada diri pembelajar. Perubahan yang dimaksud adalah perubahan prilaku berupa pengetahuan, pemahaman, keterampillan, dan kebiasaan baru yang diperoleh individu. Dalam kegiatan belajar mengajar terdapat suatu proses yang menjadi inti kegiatan belajar tersebut dengan pembelajaran yang menitikberatkan pada keterlibatan siswa dalam mempelajari sesuatu, tak terkecuali dalam mata pelajaran fisika. [1]

Ada kesan yang kuat bahwa pelajaran fisika merupakan pelajaran yang sulit untuk dipahami dan kurang menarik. Salah satu penyebabnya adalah kurangnya minat siswa untuk mempelajari fisika. selain itu, ada beberapa faktor yang menyebabkan rendahnya hasil belajar fisika diantaranya proses pembelajaran yang ditemukan secara umum lebih menekankan pada pemcapaian tuntutan kurikulum, dan sebagian besar guru belum mampu menciptakan suasana pembelajaran yang menarik dan menyenangkan, sehingga siswa kurang termotivasi dan merasa terbebani dalam belajar fisika. Pembelajaran pun lebih bersifat teacher-centerd guru hanya menyampaikan IPA sebagai produk dan siswa menghafal informasi faktual, serta kecenderungan penggunaan soal-soal bentuk pilihan ganda murni pada waktu ulangan harian maupun ulangan sumatif. Pembelajaran seperti itu akan menimbulkan ketidaktahuan pada diri siswa mengenai proses maupun sikap dari konsep fisika yang mereka peroleh. Dengan demmikian, seorang pendidik perlu menerapkan suatu model pembelajaran yang dapat menarik minat siswa untuk mempelajari ilmu fisika. Model yang digunakan harus sesuai dengan tujuan pembelajaran serta jenis materi yang diajarkan. Kurang tepatnya menggunakan model pembelajaran, dapat menimbulkan kebosanan, monoton, atau bahkan siswa kesulitan dalam memahami konsep yang diajarkan.

Berdasarkan masalah yang ada maka diperlukan adanya suatu model yang dapat melibatkan siswa secara optimal dalam pembelajaran. Salah satu model pembelajaran yang membuat siswa aktif untuk menemukan konsepnya sendiri adalah dengan penerapan model pembelajaran inkuiri terbimbing.Di dalam model pembelajaran inkuiri terbimbing terdapat lima tahapan, yaitu menghadapkan masalah, mengumpulkan informasi, mencari data dalam eksperimen, mengorganisasikannya, merumuskan, menjelaskan, dan menganalisis proses penelitian merupakan metode yang baik dilakukan oleh guru ketika melaksanakan 
pembelajaran di kelas. Karena dengan menampilkan beberapa tahapan dalam pembelajaran inkuiri terbimbing siswa tidak hanya menghafalkan banyak rumus dan menghitung saja, tetapi juga menampilkan gejala-gejala fisika yang dapat ditemui dalam kehidupan sehari-hari mereka dapat memaknai konsep-konsep fisika yang diajarkan pada akhirnya dapat menciptakan proses pembelajaran fisika yang bermakna.

Berdasarkan penjelasan di atas maka penulis mengaitkan masalah yang dialami siswa karena kurangnya pemahaman konsep dan ketertarikan siswa terhadap pelajaran fisika, serta daya tangkap siswa yang berbeda-beda, sehingga penulis mencoba untuk membuat siswa paham bukan hanya sebagai konsep saja melainkan mempraktekannya, sehingga siswa yang memiliki pemahaman daya tangkap kurang apabila guru hanya menggunakan pembelajaran konvensional saja terhadap pelajaran fisika, bisa memahami pelajaran ini dan dapat meningkatkan keterampilan penguasaan konsep belajar siswa. Tentu siswa akan yakin bahwa fisika merupakan pelajaran yang menarik.

Dari proses pembelajaran fisika yang bermakna inilah diharapkan dapat meningkatkan pemahaman konsep siswa pada mata pelajaran fisika di kelas VIII SMP Negeri 19 Palu. Pembelajaran inkuiri terbimbing membuat siswa untuk mencari dan menyelidiki suatu masalah dengan cara yang sistematis, kritis, logis dan dianalisis dengan baik.

\section{METODE PENELITIAN}

Jenis penelitian ini merupakan penelitian kuantitatif yang bersifat eksperimen quasi. Dimana desain penelitian yang digunakan adalah "one group pretest-posttest" yaitu penelitian dilakukan menggunakan satu kelas saja sebagai kelas eksperimen. [2].

Tabel 1. Desain Satu Kelompok Pretest-Posttest (one group

\begin{tabular}{cccc}
\multicolumn{4}{c}{ Pretest-Posttest design) } \\
\hline Kelompok & $\begin{array}{c}\text { Tes } \\
\text { Awal }\end{array}$ & Perlakuan & $\begin{array}{c}\text { Tes } \\
\text { Akhir }\end{array}$ \\
\hline E (Eksperimen) & $\mathrm{O}_{1}$ & $\mathrm{X}$ & $\mathrm{O}_{2}$ \\
\hline
\end{tabular}

Keterangan :

E : Kelas eksperimen

$\mathrm{O}_{1}$ : Tes awal

$X$ : Perlakuan dengan model pembelajaran inkuiri terbimbing

$\mathrm{O}_{2}$ : Tes akhir
Variabel dalam penelitian ini, yaitu pengaruh variabel model pembelajaran inkuiri terbimbing terhadap variabel pemahaman konsep siswa pada mata pelajaran fisika di SMP Negeri 19 Palu.

Populasi dalam penelitian ini adalah seluruh siswa SMP Negeri 19 Palu tahun ajaran 2015/2016 yang terdiri dari 14 kelas. Sedangkan yang menjadi sampel dalam penelitian ini satu kelas (VIIID) yang berjumlah 20 orang.

Jenis data dalam penelitian ini yaitu data primer yang bersumber dari nilai tes yang diberikan pada siswa.

\section{Tehnik pengumpulan data}

Tehnik pengumpulan data dalam penelitian ini adalah (1) tahap persiapan (2) tahap pelaksanaan (3) tahap akhi.r

\section{Instrumen Penelitian}

Instrumen yang digunakan dalam penelitian ini terdiri dari: (1) tes pemahaman konsep siswa (2) perangkat pembelajaran.

\section{Teknik Analisis Data}

\section{Uji pengaruh pemahaman konsep}

Untuk mengetahui pengaruh hasil tes pemahaman konsep yang diperoleh dengan menggunakan model pembelajaran inkuiri terbimbing dihitung berdasarkan skor $\mathrm{N}$-gain. Untuk memperoleh skor $\mathrm{N}$-gain digunakan rumus:

$g=\frac{s_{\text {post }}-s_{\text {pre }}}{s_{\text {maks }}-s_{\text {pre }}} \times 100 \%$

Keterangan:

$$
\begin{aligned}
& \text { Spost }: \text { Skor tes akhir } \\
& \text { Spre }_{\text {S }} \text { Skor tes awal } \\
& \text { Smax }_{\max }: \text { Skor maks }
\end{aligned}
$$

Tabel 2. Kriteria Tingkat Gain

\begin{tabular}{ll}
\hline Tingkat Gain (\%) & Kriteria \\
\hline $\mathrm{g} \geq 70$ & Tinggi \\
\hline $30 \leq \mathrm{g}<70$ & Sedang \\
\hline $\mathrm{g}<30$ & Rendah \\
\hline
\end{tabular}

Peningkatan hasil dari tes awal ke tes akhir yang diperoleh menunjukan pengaruh dari perlakuan yang diberikan, yaitu pemahaman konsep melalui penerapan model pembelajaran inkuiri terbimbing.

2. Uji hipotesis

Untuk menguji tingkat signifikan perbedaan skor tes awal dan tes akhir dilakukan analisis secara statistik non parametik dengan menggunakan uji-t dengan pasangan hipotesis adalah: 
$\mathrm{H}_{0}: \mu_{\text {post }}=\mu_{\text {pre }}:$ Tidak terdapat pengaruh model pembelajaran inkuiri terbimbing terhadap pemahaman konsep siswa.

$\mathrm{H}_{\mathrm{i}}$ : $\mu_{\text {post }}>\mu_{\text {pre }}$ : Terdapat pengaruh model pembelajaran inkuiri terbimbing terhadap pemahaman konsep siswa.

Dengan kriteria pengujian yakni terima $\mathrm{H}_{0} \mathrm{jika}$ $\mathrm{t}_{(1-0,5)}<\mathrm{t}<\mathrm{t}_{(1-0,5)}$ pada taraf nyata 0,05. [3].

\section{HASIL DAN PEMBAHASAN}

A. Hasil Penelitian

Setelah dilakukan perhitungan tes pemahaman konsep diperoleh data hasil penelitian seperti pada Tabel 3.

Tabel 3. Skor Tes Pemahaman Konsep

\begin{tabular}{lll}
\hline Uraian & Tes Awal & Tes Akhir \\
\hline Jumlah Sampel & 20 & 20 \\
Skor Terendah & 4 & 8 \\
Skor Tertinggi & 11 & 17 \\
Skor Rata-rata & 15,7 & 30,34 \\
Skor Ideal & 41 & 41 \\
\hline
\end{tabular}

Berdasarkan Tabel 3 dapat dilihat bahwa secara kuantitas terdapat perbedaan pemahaman konsep siswa sebelum dan sesudah diterapkannya model pembelajaran inkuiri terbimbing.

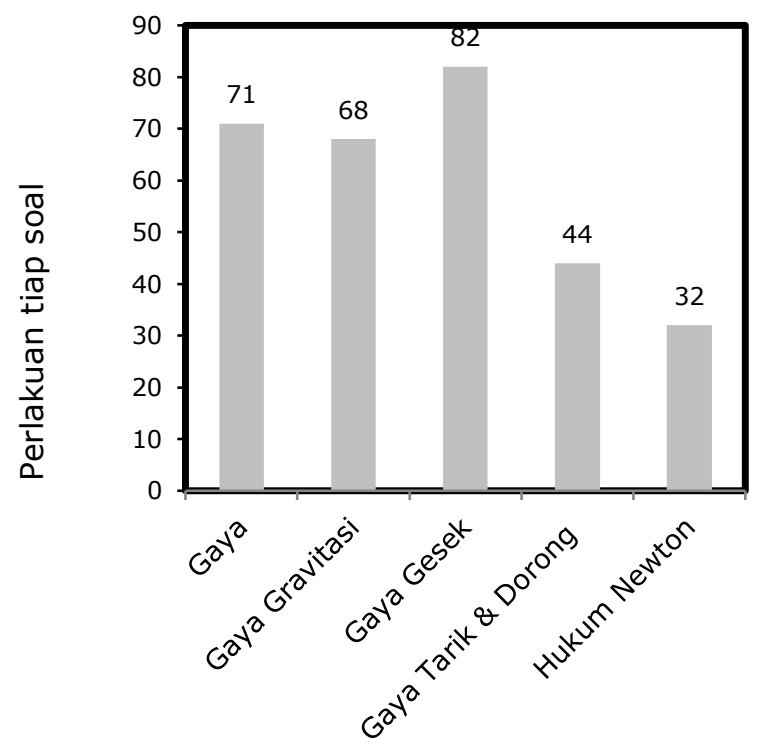

Gambar 1. Diagram Nilai N-gain RataRata Tiap Soal

Pada kelas yang diteliti setiap aspek pemahaman konsep mengalami peningkatan dan berada dalam kategori sedang (63,2\%). Data hasil tes yang diperoleh yaitu skor ratarata pada tes awal sebesar 15,7 dan skor ratarata pada tes akhir sebesar 30,35.

\section{Uji Hipotesis}

Pengujian hipotesis menggunakan statistik parametrik (uji-t). Uji ini dimaksudkan untuk mangetahui adanya pengaruh pemahaman konsep pada tes awal dibandingkan tes akhir. $\mathrm{Uji}$ ini digunakan untuk memastikan apakah hipotesis yang diajukan dapat diterima atau ditolak.

Pengujian ini menggunakan uji-t dengan pasangan hipotesis sebagai berikut:

$\mathrm{H}_{0}: \mu_{\text {post }}=\mu_{\text {pre }}: \quad$ Tidak terdapat pengaruh model pembelajaran inkuiri terbimbing terhadap pemahaman konsep siswa.

$\mathrm{H}_{\mathrm{i}}: \mu_{\text {post }}>\mu_{\text {pre }}: \quad$ Terdapat pengaruh model pembelajaran inkuiri terbimbing terhadap pemahaman konsep siswa.

Kriteria pengujian $\mathrm{H}_{0}$ diterima jika $-\mathrm{t}_{(1-0,5)}<\mathrm{t}$ $<t_{(1-0,5)}$ pada taraf nyata $a=0,05$, untuk $t$ lainnya $\mathrm{H}_{0}$ ditolah. Berdasarkan daftar distribusi diperoleh $t_{\text {tabel }}=60$, sedangkan dari hasil perhitungan uji-t diperoleh nilai thitung $=11,91$ yang berada di luar penerimaan $\mathrm{H}_{0}$ ditolak. Hal

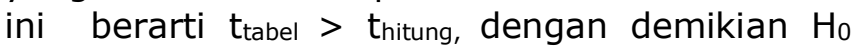
ditolak dengan taraf nyata $\mathrm{a}=0,05$ dan $\mathrm{H}_{\mathrm{i}}$ diterima. Berdasarkan hasil tersebut dikatakan bahwa terdapat peningkatan secara signifikan pemahaman konsep siswa pada skor tes awal dibandingkan dengan skor tes akhir.

B. Pembahasan

Penelitian ini bertujuan untuk mengetahui pemahaman konsep siswa SMP Negeri 19 Palu setelah diterapkan model pembelajaran inkuiri terbimbing. Langkah-langkah pembelajaran yaitu, penyajian materi diawali dengan sebuah permasalahan untuk menarik minat para siswa dalam belajar dan juga untuk mengetahui tingkat pemahaman konsep siswa. Tes tersebut berisi fenomena dalam kehidupan sehari-hari sehingga diharapkan dapat memecahkan permasalahan.

Terdapat 1 kelas dalam penelitian ini yaitu kelas VIIID yang jumlah siswanya sebanyak 20 orang. Setelah diterapkan model pembelajaran inkuiri terbimbing dimana siswa diberikan kesempatan untuk mengajukan pendapatnya bila ada masalah, diperoleh hasil penelitian yang menunjukkan bahwa kelas tersebut mengalami peningkatan pemahaman konsep, dengan perolehan rata-rata $\mathrm{N}$-gain sebesar $63,2 \%$.

Peningkatan pemahaman konsep siswa kelas VIIID SMP Negeri 19 Palu berbeda-beda tiap butir soal yang diberikan. Hal ini disebabkan 
karena setiap butir soal memiliki tingkat kesukaran yang berbeda-beda.

Sesuai dengan penelitian sebelumnya bahwa kelas yang hanya terpaku dengan apa yang dikatakan guru tingkat pemahaman konsepnya rendah dibandingkan dengan model pembelajaran yang membuat siswa aktif dalam proses belajar mengajar. [4]. Hal tersebut terbukti dalam penelitian ini dimana guru kelas VIIID hanya menggunakan metode ceramah dalam proses belajar mengajar sehingga skor tes pemahaman konsep siswa terdapat perbedaan yang signifikan antara tes awal dan tes akhir.

Menurut referensi [5] bahwa model pembelajaran inkuiri terbimbing adalah cara menyajikan pelajaran yang memberikan kesempatan kepada siswa untuk menemukan informasi tanpa bantuan guru, sedangkan menurut referensi [6] siswa yang aktif dapat menggabungkan beberapa fakta yang diperolehnya dan dapat menyelesaikannya masalah yang diberikan sehingga dapat merangsang pemahaman konsep siswa.

Setelah dilakukan uji hipotesis dengan menggunakan uji-t di peroleh thitung $=11,91$ dan $t_{\text {tabel }}=60$ pada taraf nyata $a=0,05$. Nilai yang diperoleh tabel $>$ thitung, dengan demikian $\mathrm{H}_{0}$ ditolak dengan taraf nyata $\mathrm{a}=0,05$ dan $\mathrm{H}_{1}$ terima. Berdasarkan hasil penelitian tersebut diketahui bahwa terdapat peningkatan secara signifikan pemahaman konsep siswa pada skor tes akhir dibandingkan dengan skor tes awal. Alasan digunakannya uji-t dalam penelitian ini yaitu sampel yang digunakan tergolong sampel kecil dan dari desain penelitian yang ada yaitu menggunakan satu kelas.

Skor tes awal diketahui bahwa pemahaman konsep siswa rendah, hal ini disebabkan karena model pembelajaran yang dilakukan hanya menuntut siswa mendengarkan apa yang disampaikan oleh guru sehingga siswanya tidak aktif dan tidak mengasah pemahaman konsep siswa.

Penelitian sebelumnya menyimpulkan bahwa dengan menerapkan model pembelajaran inkuiri terbimbing dapat meningkatkan prestasi belajar fisika dan pemahaman konsep siswa. [7]. Dari hasil penelitian tersebut memperlihatkan adanya peningkatan antara pemahaman konsep siswa terhadap hasil belajar. Dimana dengan meningkatkan pemahaman konsep siswa meningkat pula hasil belajarnya. Berdasarkan penjelasan di atas jelas bahwa model pembelajaran inkuiri terbimbing dapat mengetahui pengaruh pemahaman konsep siswa. Dengan demikian model pembelajaran inkuiri terbimbing dapat dijadikan sebagai salah satu alternatif dan proses belajar mengajar untuk meningkatkan pemahaman konsep siswa.

\section{KESIMPULAN DAN SARAN}

Berdasarkan hasil penelitian dan analisis data maka dapat disimpulkan bahwa terdapat pengaruh model pembelajaran inkuiri terbimbing terhadap pemahaman konsep siswa. Pada kelas yang diteliti setiap aspek pemahaman konsep mengalami peningkatan dan berada dalam kategori sedang $(63,2 \%)$. Data hasil tes yang diperoleh yaitu skor ratarata pada tes awal sebesar 15,7 dan skor ratarata pada tes akhir sebesar 30,35. Hasil uji statistik yang diperoleh yaitu nilai tabel $=60$, sedangkan dari hasil perhitungan uji-t diperoleh nilai thitung $=11,91$ yang berada di luar penerimaan $\mathrm{H}_{\circ}$ ditolak. Hal ini menunjukkan bahwa tabel berada pada daerah penolakan $\mathrm{H}_{\mathrm{o}}$, yakni $\mathrm{H}_{\mathrm{o}}$ diterima jika $-\mathrm{t}_{(1-0,5)}<\mathrm{t}<\mathrm{t}_{(1-0,5)}$ pada taraf nyata $a=0,05$, Atau penelitian ini menunjukkan bahwa hipoteses $\left(\mathrm{H}_{\circ}\right)$ ditolak dan hipotesis penelitian $\left(\mathrm{H}_{\mathrm{i}}\right)$ diterima.

\section{DAFTAR PUSTAKA}

[1] Trianto. (2009). Mendesain Model Pembelajaran Inovatif-Progresif: Konsep, Landasan dan Implementasinya pada Kurikulum Tingkat Satuan Pendidikan (KTSP). Jakarta: Kencana Prenada Media.

[2] Arikunto, S. (2006). Prosedur Penelitian: Suatu Pendekatan Praktek. Jakarta: PT. Rineka Cipta.

[3] Sudjana. (2005). Metode Statistik. Bandung: CV Tarsito.

[4] Permata, N. (2012). Penuntun Belajar Kreatif. Depok: Pelita.

[5] Sumantri. (1999). Strategi Pelajar Mengajar. Bandung: CV Maulana.

[6] Fitriani. (2012). Pengaruh Model Pembelajaran Inkuiri Terhadap Hasil Belajar Fisika Pada Pokok Bahasan Gerak. Skripsi Tidak Diterbitkan. Jakarta: UIN Syarif Hidayatullah. 